\title{
Pathological Fractures of the Proximal Femur Due to Metastatic Lesions: A Single Institution Experience of Patient Characteristics and Methods of Surgical Treatment
}

\section{Proksimal Femur Patolojik Kırıkları Sonrası Seçilen Cerrahi Tekniğin ve Hasta Özelliklerinin Uzun Dönem Sürviye Etkileri}

\author{
(D) Yavuz Sağlam¹, (D) Barış Gülenç², (D) Fevzi Birişik ${ }^{3}$, (D) Onur Tunalı4, (1) Ahmet Salduz³ , (D) Önder Yazıcıoğlu³ \\ lisstanbul Biruni Univercity Faculty of Medicine, Department of Orthopedics and Traumatology, İstanbul, Turkey \\ ${ }^{2}$ istanbul Medipol Univercity Faculty of Medicine, Department of Orthopedics and Traumatology, İstanbul, Turkey \\ 3istanbul University İstanbul Faculty of Medicine, Department of Orthopedics and Traumatology, İstanbul, Turkey \\ ${ }^{4}$ Istanbul Acıbadem Hospital, Clinic of Orthopedics and Traumatology, İstanbul, Turkey
}

\begin{abstract}
Objective: Pathological fractures are among the most common complications of malign neoplasms. The femur is the most frequently involved bone following spinal metastasis. This study retrospectively analyzed patients who had been surgically treated for proximal femur metastasis and aimed to determine the factors that affect survival rates.

Methods: This is an IRB approved, retrospective review of all patients diagnosed with pathological fractures due to proximal femur metastasis and treated surgically in a single institution from 2004 to 2012. The Karnovsky scoring system was also used to evaluate functionality. Statistical comparisons were made by forming patient subgroups based on the existence of a primary diagnosis, the surgical method selected, and the existence of complications. The analyses attempted to recognize the factors that affect mortality.

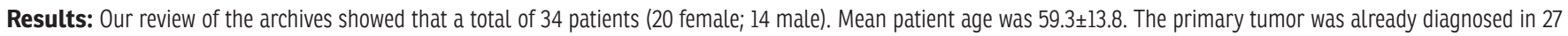
patients on admission. Pathological fractures seemed to occur at an average of $53.4( \pm 44.5)$ months after primary diagnosis. Long-stemmed cemented arthroplasty was used in 15 patients and IM nail was used in 19 patients. Patients with IM nail were mobilized significantly earlier and hospitalization was shorter respectively $(p=0.04, p=0.006)$. The need for a second surgical operation was statistically similar in the two groups ( $\mathrm{p}=0.24$ ). After an approximate follow-up of $26.5 \pm 21.9$ months, the average Karnovsky score was similar (54.1 vs. $48.3 ; p=0.07)$. The patients who did not have a second skeletal system metastasis or other organ metastasis survived significantly longer $(24.7 \mathrm{vs}$. 11.3; $\mathrm{p}=0.02)$.
\end{abstract}

Conclusions: Shorter hospitalization and earlier mobilization can be in patients who were treated with an IM nail. Higher survival is expected for patients who do not have distant organ or skeletal system metastases at the time of surgically treating pathological fractures.

Level of evidence: - IV: retrospective series

Keywords: Pathologic femur fracture, intramedullary nailing, cemented arthroplasty, karnovsky score

ÖZ

Amaç: Kemik metastazları,kanser hastalarının ciddi komplikasyonlarından birisi olup tedavisi hastaların hızlı mobilize edilmesi ve ağıı kontrolu için esastır. Özellikle son dönemlerde medikal onkolojk tedavinin de gelișmesi ile kemik metastazlarına sahip hastalarda da uzun yașam beklenmekte ve bu nedenle bu lezyonların tedavisinde cerrahiye yönelim artmıştır. Biz bu çalıșmada femur proksimal uç metastazlarında en yaygın tercih edilen iki cerrahi yöntem olan intrameduller osteosentezi ve protez ile rekonstüksiyonunun, hastaların diğer özellikleri de ele alınarak sürviye olan etkisi üzerinde çalıșıldı.

Yöntemler: Çalıșmada, 2004-2013 yılları arasında kliniğimizde opere olan proksimal uç metastazı olan 34 hasta retrospektif olarak değerlendirildi. Hastaların ortalama yașı $59,3 \pm 13,8$ idi. 27 hastada primer tanı bilinmekte idi. Patolojik kırıklar primer tanı sonrası ortalama $53,4( \pm 44,5)$ ayda ortaya çıktı̆ı görüldü.l5 hastada uzun stemli femoral protez yapıırken, 19 hastada intramedüller çivi ile tespit yapııdı.

Bulgular: İntramedüller çivi grubunda hastanede yatış süresi ve mobilizasyon süresi protez grubuna göre anlamlı düzeyde az olduğu görüldü ( $p=0,04$, p=0,006). íkincil cerrahi gereksinimi arasında iki grup arasında anlamlı düzeyde fark yoktu( $\mathrm{p}=0,24) .26,5 \pm 21,9$ ay takip süresi sonrasında her iki grup arasında ortalama karnofsky skorları benzerdi (54,1 vs. 48,3; $p=0,07)$. iskelet ve uzak organ metastazı olmayan hastaların anlamlı düzeyde daha uzun sürvi sahibi olduğu görüldü $(24,7$ vs. 11,3; p=0,02).

Sonuç: Patolojik proksimal femur kırıkları sonrası IM çivi uygulaması hastanede kalış süresi ve mobilizasyona geçiş süresini azaltmaktadır. Uzak organ ve iskelet metastazı olmayan hastaların uzun dönem sürvileri daha uzun olmaktadır.

Kanıt düzeyi: IV retrospektif çalışma

Anahtar Kelimeler: Patolojik kırık, intramedüller çivi, çimentolu artroplasti, performans durumu

Received/Geliș tarihi: 08.01.2018 | Accepted/Kabul tarihi: 23.04.2018

Address for Correspondence/Yazıșma Adresi: Barış Gülenç, İstanbul Medipol Univercity Faculty of Medicine, Department of Orthopedics and Traumatology, İstanbul, Turkey

Phone/Telefon: +90 5308256310 E-mail/E-posta: barisgulenc@yahoo.com ORCID-ID: orcid.org/0000-0002-4565-2315

Citation/Atıf: Sağlam Y, Gülenç B, Birișik F, Tunalı O, Salduz A, Yazıcıoğlu Ö. Pathological Fractures of the Proximal Femur Due to Metastatic Lesions: A Single Institution Experience of Patient Characteristics and Methods of Surgical Treatment. Bakırköy Tip Dergisi 2019;15:155-9. https://doi.org/10.4274/BTDMJB.galenos.2018.20180423062907 


\section{INTRODUCTION}

Approximately $80 \%$ of advanced carcinoma patients exhibit radiological evidence of skeletal metastases (1-3). The spine and pelvis are the most common sites, followed by the femur with an incidence of 30 to $50 \%(3,4)$. Majority of all femoral metastases are located at the proximal femur $(2,3,5,6)$. With the increase in the global survival of patients with bone metastasis, it is important to establish defined protocols for clinical and surgical approaches aiming to improve the quality of local control of the bone injury, even before the occurrence of a pathologic fracture, and to maintain such stabilization for many years (7). When a pathologic fracture occurs at the proximal femur, the surgical treatment is technically demanding (8). Orthopedic advances in osteosynthesis and endoprosthesis have benefited prevention and treatment of such fractures $(7,9)$. However, to date there is no consensus as to the best treatment choice.

Any treatment of metastases and pathological fractures should accurately assess the activity of the disease, its involvement in the body, and expected lifetime as well as take into consideration the general condition and expectations of the patient. Pathological fractures in the

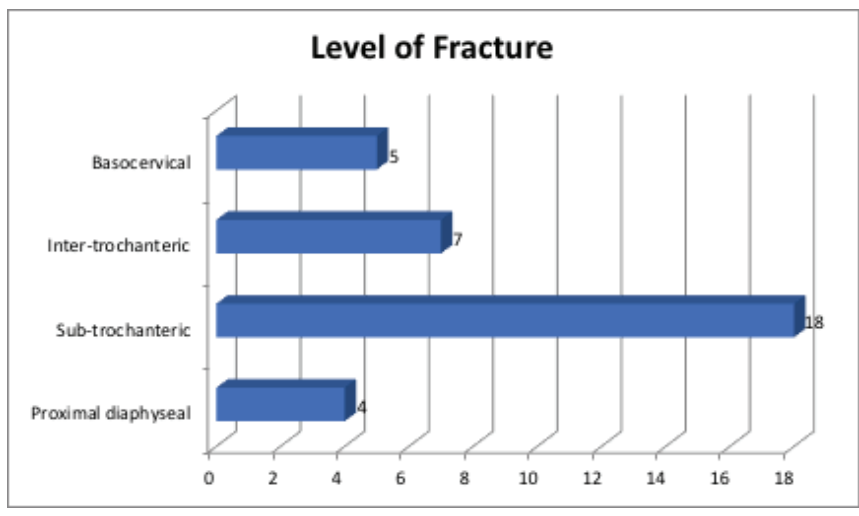

Figure 1: The level of pathologic proximal femur fractures due to metastasis

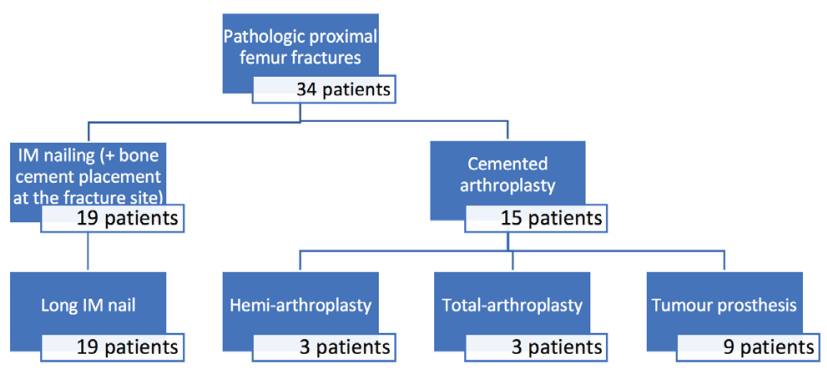

Figure 2: Selected surgical methods for treatment lower limbs have devastating consequences on the quality of the remaining life in these patients $(6,10)$. Immediate fixation or prosthetic replacement provides pain relief, psychological improvement and restoration of the physical functions $(2,3)$.

In this study, we aimed to evaluate a comparatively large series of patients operated for metastatic proximal femur fracture to describe patient characteristics and survival rates. Moreover, we include the type of treatment received, intramedullary nailing or prosthetic replacement, for comparison.

\section{METHODS}

This is an institutional review board (IRB) approved retrospective review of all patients diagnosed with pathological fracture of the proximal femur due to a metastatic lesion and received surgical treatment at a single institution from 2004 to 2012. Patients with a diagnose of proximal femur metastasis without fracture and patients who did not operated due to life expectancy shorter than 2 months or additional serious comorbidities were excluded.

The surgical treatment modality and implant used, duration of hospitalization and mobilization, the period between diagnosis and metastasis, and complications were analyzed in detail. The surgical method is determined by considering the functional capacity and expected lifetime of the patient and the configuration of the fracture. Satellite lesions were detected by scanning the whole femur and acetabulum with plain radiography before operation. The patients were allowed limited weight bear with the help of two crutches or walker 2 days after the surgical intervention.

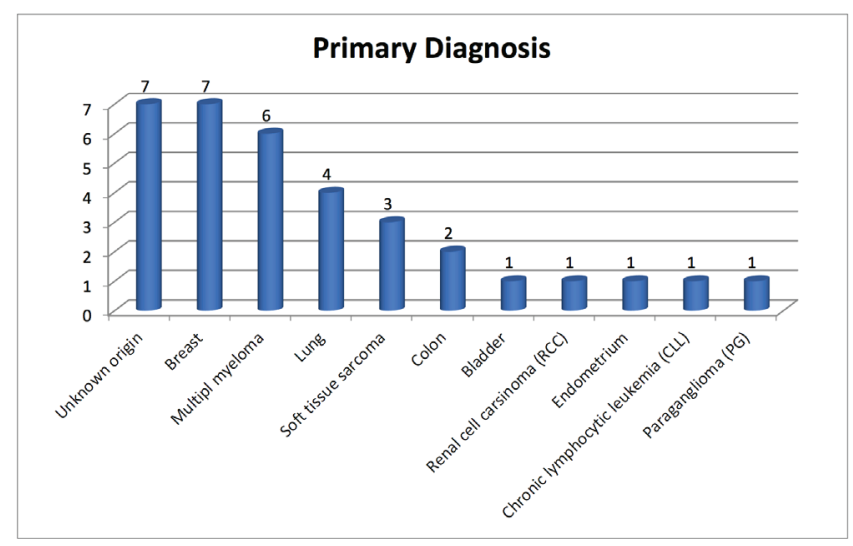

Figure 3: Primary diagnosis of the patients 
The average lifetime of patients after the surgical treatment was recorded with the information obtained from their families. For those who are still alive, survival was defined by taking the last control or phone call date as reference.

Further statistical comparisons were made by forming patient subgroups based on the existence of a primary diagnosis, the surgical method selected, and the existence of complications.

\section{Statistical Analyses}

Statistical analyses were performed using student t-test for parametric data, the Mann-Whitney $U$ (Wilcoxon rank test) test for non-parametric data, and the chi-squared test for categorical data as appropriate. A $p$ value of $\leq 0.05$ was considered significant.

\section{RESULTS}

Thirty-four patients (20 female; 14 male) were included in this study. Mean age at pathologic fracture was $59.3 \pm 13.8$ (range 31-89). The primary diagnose of the cancer was already known in 27 patients on initial orthopedic admission. Seven patients had pathological proximal femur fractures by an unknown neoplasm. The fracture was basicervical in 5 , intertrochanteric in 7, subtrochanteric in 18 and proximal diaphyseal in 4 patients. At the time of diagnosis, 22 had a detected metastasis in another part of the skeletal system and 14 had a detected metastasis in a visceral or solid organ.

Long-stemmed cemented arthroplasty (Mutars/ Implantcast, Germany; Pentamuts/Tipsan, Turkey; TMTS/ Hipokrat, Turkey; Echelon/Smith-Nephew, USA) was used in 15 patients, while IM nail (LFNA-PFNA/Syntes, Switzerland) was used in 19 patients.

Pathological fracture occurs at an average of 53.4 $( \pm 44.5)$ months after primary diagnosis of the neoplasm. Retrospective analyses showed that the patients who were treated with IM nail had a longer history of cancer than patients treated with cemented arthroplasty (69.3 months vs. 31.8 months; $p=0.003$ ).

Patients with IM nail were mobilized significantly earlier than those who had prosthetic replacement (2.1 vs. 3.8 days, $p=0.04$ ). Only one patient failed to mobilize due to terminal stage of the primary disease. Mean hospitalization period after operation was $4.9 \pm 3.3$ days. When the surgical methods were compared, it was found that hospitalization period was significantly shorter in intramedüller (IM) nail patients than the prosthesis group (3.3 vs. 6.9, $p=0.006$ ).

Five patients needed further surgeries. The PFNA was revised to a prosthetic replacement because of implant failure in one patient. Periprostatic fractures occurred at the tip of PFNA in two patients who underwent an exchange nailing with long IM nail (LFNA). Infection was seen in one patient who had been on prolonged antibiotic treatment. Early luxation was seen in two patients and revised with a constrained prosthesis. The need for a second surgical operation was statistically similar in both groups according to surgical method selection $(p=0.24)$.

An average of $26.5 \pm 21.9$ months post-operatively phone calls were made to the families to find out the survival rates and the functional status of the patients. Twenty six of the 34 patients were died; 3 were able to mobilize without any supportive device; and the remaining five were able to mobilize with the help of a walker.

\section{DISCUSSION}

The treatment of pathological fractures of the proximal femur due to metastatic lesions remains challenging. Successful management of bony metastases requires a multidisciplinary approach, and the implants should last for the remaining lifetime of the patient if operation becomes necessary (11). Cemented arthroplasty and IM nailing \pm cement application to the fracture site are the frequently preferred methods whose advantages are stated in the literature for proximal femur pathologic fractures $(4,8,11)$.

IM nailing is a safe and reliable method for pain relief and ambulation due to its short surgical time, minimal incision, quick mobilization and early ambulation $(12,13)$. Prolonged operating and anesthetic times in already debilitated patients along with surgical stresses could have wide-ranging effects on long-term survival secondary to hypotension, cardiac arrest, pneumonia, fat embolism, adult respiratory distress syndrome, and wound infection (3,14-16). Filling the metastatic part of the bone by cement and performing radiotherapy after surgery are also recommended in the literature for patients with IM nails (13). In this study, intramedullary nail was used in 19 patients; subtrochanteric fracture in 15 and proximal diaphyseal in 4 patients. IM nails which have their entry point in the piriformis fossa have a tendency to displace the proximal fragment into varus or may even explode 
the proximal femur during insertion (8). PFNA and LFNA was used, which both have insertion point at or slightly lateral to the tip of greater trochanter. Except having a few technical problems during surgery, we had no mechanical failures related to the LFNA in our series. But we had mechanical problems with PFNA such as, implant failure in one and periprosthetic fracture in two patients which were converted to LFNA. Therefore we prefer no longer to use PFNA in patients with pathologic fractures of proximal femur due to metastasis.

Longer survival estimates are thought to require more invasive procedures and more durable implants, such as prosthetic replacements, which can be expected to outlast the patient, but have their own unique set of complications. $(10,11,17)$. They advocate that extensive bone damage often required internal stabilization of the entire femur from the femoral neck down to the supracondylar area (17). The use of the long-stem femoral component in total hip replacement may allow treating the acetabular disease and femoral lesions at the same time. In this study, longstemmed cemented arthroplasty was used in 15 patients; basocervical fracture in 5, intertrochanteric fracture in 7 and subtrochanteric fracture in 3 patients.

Patients who were treated with IM nail were mobilized and discharged from inpatients unit significantly earlier respectively $(p=0.04, p=0.006)$ which may influence patients remaining life. The fact that hospitalization was longer for patients who were reconstructed by prosthesis may be attributed to delayed mobilization and the higher risk of wound site problems.

This study showed that the patients who were treated with IM nail had a longer history of cancer than patients treated with cemented arthroplasty $(\mathrm{p}=0.003)$. As primary tumors displayed a heterogenic distribution in this study, a comparison between pathological fractures with different primary causes was not made. However, patients with solitary proximal femur metastasis were found to live significantly longer than patients with systemic metastases, after surgery $(p=0.02)$. This result reveals that the existence of another metastasis in patients with pathological fractures is a valuable factor in planning the type of palliation.

Patients with metastatic bone disease have a highly variable and unpredictable prognosis of survival. Survival rates after surgery is highly dependent on patient selection, type of primary tumor, surgical method selection and existence of visceral organ metastases $(2,7,10,14)$. The risk of death in the first year after surgery was over seven times higher compared with non-pathological fractures (10).

Weiss et al. (10) reported that two-thirds of their patients were able to walk both at 6 weeks and 6 months after surgical stabilization of metastatic proximal femur fracture and they achieved good pain relief. In this study, approximately two-thirds of the patients were died at 26 months followup. Only $10 \%$ of the patients were able to mobilize without any supportive device. The most important risk factor for re-surgery is long survival rate $(2,8,10,11)$. Renal related tumors and metastasis after breast carcinoma have been reported to increase the re-surgery risk (10). The literature also underline that the complications of IM nail might be more complicated to treat $(10,11)$.

This study has some limitations, most of which are inherent to its retrospective design. Assessment of clinical outcomes was limited to chart documentation, which was incomplete in some cases as can be expected in a long-term study of this nature. Changes in selection of surgical method during 8 years of the study period may influence the results.

This study has several strengths. Sample size is relatively high and includes both treatment modalities. Despite significant efforts made to contact all patients, including public record searches, many patients were unable to be located and not included in this cohort.

\section{CONCLUSION}

In conclusion, longer survival can be expected for patients who do not have visceral organ or multiple bone metastases at the time of surgery. We recommend using long IM nail fixation for subtrochanteric and proximal diaphyseal femur fractures in combination with screw insertion to the femoral neck and cement insertion to the metastatic area to improve the local control of the disease. Hospitalization is shorter and mobilization is earlier in patients who were treated with an IM nail. Although operation time, anesthesia time and hospitalization is longer, and blood loss is more, cemented prosthetic replacement should be preferred when the proximal femoral bone stock has been weakened by the metastatic disease and the nail is unlikely to provide a stable fixation. Further studies are needed to define more specific indications for each method. 


\section{Ethics}

Ethics Committee Approval: Retrospective study.

Informed Consent: Informed consent was obtained from all individual participants included in the study.

Peer Review: Externally and internally peer-reviewed.

\section{Authorship Contributions}

Concept: O.T., Design: O.T., Data Collection or Processing: B.G., O.T., Analysis or Interpretation: B.G., Ö.Y., F.B., Literature Search: A.S., Writing: Y.S.

Conflict of Interest: No conflict of interest was declared by the authors.

Financial Disclosure: The authors declared that this study received no financial support.

\section{REFERENCES}

1. Beals RK, Lawton GD, Snell WE. Prophylactic internal fixation of the femur in metastatic breast cancer. Cancer. 1971;28:1350-4.

2. Habermann ET, Sachs R, Stern RE, Hirsh DM, Anderson WJ Jr. The pathology and treatment of metastatic disease of the femur. Clin Orthop Relat Res. 1982;70-82.

3. Sharma H, Bhagat S, McCaul J, Macdonald D, Rana B, Naik M. Intramedullary nailing for pathological femoral fractures. J Orthop Surg (Hong Kong). 2007;15:291-4.

4. Samsani SR, Panikkar V, Georgiannos D, Calthorpe D. Subtrochanteric metastatic lesions treated with the long gamma nail. Int Orthop. 2003;27:298-302.

5. Arvinius C, Parra JL, Mateo LS, Maroto RG, Borrego AF, Stern LL. Benefits of early intramedullary nailing in femoral metastases. Int Orthop. 2014;38:129-32.

6. Broos PL, Rommens PM, Vanlangenaker MJ. Pathological fractures of the femur: improvement of quality of life after surgical treatment. Arch Orthop Trauma Surg. 1992;111:73-7.
7. Narazaki DK, de Alverga Neto CC, Baptista AM, Caiero MT, de Camargo OP. Prognostic factors in pathologic fractures secondary to metastatic tumors. Clinics (Sao Paulo). 2006;61:313-20.

8. Ramakrishnan M, Prasad SS, Parkinson RW, Kaye JC. Management of subtrochanteric femoral fractures and metastases using long proximal femoral nail. Injury. 2004;35:184-90.

9. Hansen BH, Keller J, Laitinen M, Berg P, Skjeldal S, Trovik C, et al. The Scandinavian Sarcoma Group Skeletal Metastasis Register. Survival after surgery for bone metastases in the pelvis and extremities. Acta Orthop Scand Suppl. 2004;75:11-5.

10. Weiss RJ, Ekström W, Hansen BH, Keller J, Laitinen M, Trovik C, et al. Pathological subtrochanteric fractures in 194 patients: a comparison of outcome after surgical treatment of pathological and nonpathological fractures. J Surg Oncol. 2013;107:498-504.

11. Wedin R. Surgical treatment for pathologic fracture. Acta Orthop Scand Suppl. 2001;72:2p., 1-29.

12. Curtis MJ, Jinnah RH, Wilson V, Cunningham BW. Proximal femoral fractures: a biomechanical study to compare intramedullary and extramedullary fixation. Injury. 1994;25:99-104.

13. Obert $L$, Jarry $A$, Lepage $D$, Jeunet $L$, Tropet $Y$, Vichard $P$, et al. [Centromedullary nailing of the femur for bone metastasis: clinical and radiological evaluation using the Tokuhashi score in 24 patients]. Rev Chir Orthop Reparatrice Appar Mot. 2005;91:737-45.

14. Behr JT, Dobozi WR, Badrinath K. The treatment of pathologic and impending pathologic fractures of the proximal femur in the elderly. Clin Orthop Relat Res. 1985;173-8.

15. Broos P, Reynders P, van den Bogert W, Vanderschot P. Surgical treatment of metastatic fracture of the femur improvement of quality of life. Acta Orthop Belg. 1993;59 Suppl 1:52-6.

16. Dijstra S, Wiggers T, van Geel BN, Boxma H. Impending and actual pathological fractures in patients with bone metastases of the long bones. A retrospective study of 233 surgically treated fractures. Eur J Surg. 1994;160:535-42.

17. Lane JM, Sculco TP, Zolan S. Treatment of pathological fractures of the hip by endoprosthetic replacement. J Bone Joint Surg Am. 1980;62:954-9. 